\title{
METHODOLOGICAL BASES RESEARCH OF THE INNOVATIVE CULTURE DEVELOPMENT OF THE FUTURE MANAGER OF GENERAL SECONDARY EDUCATIONAL INSTITUTION IN THE MASTERS' TRAINING PROCESS
}

The research methodology of the problem of the innovative culture development of the future manager of the general secondary educational institution in the master's training process corresponds to the topic specifics and takes into account its systemicity and interdisciplinarity. In view of this, theoretical and methodological principles are considered at four scientific levels: philosophical; specifically scientific; conceptual and theoretical; methodological and technological. This approach allowed to build research taking into account the necessary philosophical and scientific-theoretical provisions, to adhere to those methodological guidelines that ensure the scientific analysis, strengthen the presentation logic, focused on the study integrity and comprehensiveness.

The article proposes a model of the research methodology of theoretical and methodical bases of the innovative culture development of the future manager of general secondary educational institution in the masters' training process, in which philosophical, concrete-scientific, conceptual-theoretical and methodologicaltechnological levels are structurally organized. It is noted that at the philosophical methodological level the heuristic possibilities of dialectical theory, systemic and synergetic methodological approaches are outlined and a number of principles of scientific and pedagogical research are traced. It is pointed out that at the level of concrete-scientific methodology the methodological potential of professional-pedagogical, anthropological, sociocultural, culturological, paradigmatic, civilizational, formational, axiological, problematic, thesaurus, phenomenological, acmeological, acmeological, diaxological, diaxological, diaxeological and praxeological is integrated. It is presented that at the third conceptual-theoretical level the leading provisions of modern theory of pedagogical cognition, professional pedagogy are systematized, scientific generalizations on methods of the innovative culture development of personality are studied, provisions of leading state and international documents regulating innovations and innovative activity development are taken into account. It is determined that at the fourth methodological and technological level a set of general theoretical, empirical and special methods is presented, which allowed to carry out the necessary operations on empirical collection, theoretical analysis and generalization of research materials. The corresponding methodological model reveals to the tasks set in the article, and also takes into account the interdisciplinary specifics of the research subject.

Key words: innovation, innovative culture, future manager, secondary educational institution, methodological bases, methodological approaches.

Formulation of the problem. In the modern period before the system of higher education of Ukraine, which is at the stage of its essential transformation in the realities of the globalized society of the XXI century, the problem of such educational process organization at higher educational institutions (HEI) is urgent, effective work, professionally mobile and competitive in the labor market future professionals, in particular future managers of the general secondary educational institutions. Therefore, there is a need for methodological bases research of the innovative culture development of the future manager of general secondary educational institution in the masters' training process.

State of research. Analysis of pedagogical, psychological, philosophical and management sources, including in the educational field, shows that various aspects of the problem are reflected in the following areas of scientific thought: theoretical aspects of management in foreign research (M. Albert, M. Arrmstrong, P. Drucker, M. Mescon, A. Strickland, F. Taylor, A. Thompson, D. Waters, F. Hedoury, D. Sheldrake, etc.) and domestic scientists (M. Telenkov, F. Khmil, A. Shegda, G. Shchokin, V. Yatsura and others); educational pedagogical management (O. Antonyuk, M. Hrynyova, L. Kalinina, L. Karamushka, N. Kolominsky, I. Likarchuk, V. Maslov, etc.); management of the educational institution (L. Vashchenko, A. Guba, L. Danylenko, G. Yelnikova, O. Kasyanova, V. Kryzhko, V. Oliynyk, T. Rohova, A. Kharkivska, E. Khrykov, etc.).

The problem of methodology analysis of pedagogical phenomena is presented in researches of the leading Ukrainian and foreign methodologists, in particular such as O. Adamenko, S. Batishev, V. Bezrogov, S. Bobryshov, M. Boguslavsky, 
G. Vasyanovich, L. Vakhovsky, S. Goncharenko, B. Kornetov, V. Kurilo, V. Kremen, V. Onishchenko, V. Pokas, A. Sbrueva, S. Sysoeva, O. Sukhomlynska, E. Khrykov, E. Yudin, M. Yarmachenko and others. Researchers pay attention to the need for validity, systematization and contextuality of scientific conclusions, also attention is paid to the importance of accuracy and correctness of scientific research thesaurus, outline ways to integrate methodological approaches that provide a comprehensive, in-depth, sound and systematic problem study. Substantiating the choice of methodological principles of our study, it should be emphasized that its heuristic potential is primarily aimed at the importance of pedagogy to perform theoretical and practical functions.

The purpose of the article - to find out methodological bases research of the innovative culture development of the future manager of general secondary educational institution in the masters' training process.

Results of the research. Development and substantiation of theoretical and methodical bases of the innovative culture development of the future manager in the masters' training process requires a systematic problem vision, the achievement of which depends on correctly and motivated research strategy, methodological, theoretical and technological tools. First of all, the methodological research of a culture which consists of methodological reflection, ability to scientific substantiation, critical thinking and creative application of certain concepts, norms and cognition methods, management, construction, etc. [6, p. 67]. Prominent Ukrainian methodologist $\mathrm{N}$. Nychkalo linked the research methodology with the solution of the main pedagogy tasks, which, in her opinion, are related to the establishment of education patterns, these processes training and management; study and generalization of practice and experience of pedagogical activity; elaboration of new teaching methods, means, forms and systems, education, management of educational structures; forecasting educational systems development for the near and distant future; implementation of the pedagogical research results in practice; elaboration of theoretical and methodological bases of innovation processes, etc. [8, p. 43]. We support the opinion of the scientist that the research methodology of the raised pedagogical problem should be directed on the consistent decision of the tasks defined in scientific search, and also to be focused on integral and system comprehension of the research subject.

Given the interdisciplinary nature of research, in our opinion, the value is the E. Yudin's scientific approach, who identified four levels of methodological knowledge: philosophical, which includes the leading provisions of the dialectical knowledge theory, science principles, integrity, research comprehensiveness and complexity; general scientific, which is represented by systematic and paradigmatic approaches to the scientific problem analysis; specifically scientific, representing the methodology of a single pedagogical study; technological methodology, which combines the methodology and techniques of scientific research, allows to obtain reliable empirical and theoretical material [9].

In our opinion, the methodology of the problem research of the innovative culture development of the future manager of general secondary educational institution in the masters' training process should corresponds to the specifics of the topic and take into account its systemics and interdisciplinarity. Given this, it is considered the theoretical and methodological principles at four scientific levels: philosophical; specifically scientific; conceptual and theoretical; methodological and technological. This approach will allow to build research taking into account the necessary philosophical and scientific-theoretical provisions, to adhere to those methodological guidelines that will ensure the scientific analysis, strengthen the logic of the presentation, focus on the research integrity and comprehensiveness.

The philosophical level of theoretical and methodological principles is represented by the research construction on the basis of dialectical cognition theory, leading laws and principles of scientificanalysis, priorities of system and synergetic methodology, which allows to consider the problem taking into account the principles of interdependence and interdependence, development and selfdevelopment, systemics and determinism, etc.

Dialectical cognition theory makes it possible to analyze the main category of research "development", taking into account the dialectical change understanding, which defines development as a natural, irreversible, directed, qualitative and necessary change of material and ideal objects [5]. Dialectical understanding of the processes of global progress provides opportunities to identify the principles of the innovative culture of the future manager of general secondary educational institution, among which the priority are the principles of polyparadigmism, cultural conformity, digitalization, dynamism, flexibility, humanization, freedom, etc.

Of exceptional importance for the study of ways to develop the individual's innovative culture is taking into account the basic development laws and patterns, in particular the law of transition from quantitative to qualitative changes; the law of unity and the struggle of opposites; law of negation. The theoretical potential of the first makes it possible to streamline the model of the innovative culture development of the future manager of general secondary educational institution and to identify its main stages: motivational-cognitive, professionalpractical, creative-activity and professional-relevant. 
The dialectical idea that the certain content accumulation of educational material and practical training will provide a certain level of personal and professional competencies of the future manager of general secondary educational institution contributes to structuring the content of educational material in modeling the process of master training, allows to clearly formulate its expected results. The dialectical law of unity and struggle of opposites is also important, which orients the research taking into account the widest possible range of factors influencing the process of the innovative culture development, helps to comprehend it from the point of view of favorable and unfavorable conditions. Finally, the dialectical law of negation denies the idea that the model for the innovative culture development of the future manager of general secondary educational institution should be based on a previous bachelor's program, and don't avoid the idea of selfeducation as a key condition for self-development.

The dialectical methodology value is that its tools allow us to consider the process of the innovative culture development of the individual through the idea prism of development as something that necessarily combines both previous life experience and innovations of the proposed masters' training; as a movement, the source of which is the contradictions of personal, professional, socio-cultural, political, planetary and personal development, etc.

Dialectical development theory directs research to the observance of the basic principles of scientific research, which ensure the achievement of dialectical truth, the known criteria of which are logic, practice or conventionalism. Among the set of known important principles of scientific research for the model substantiation of the innovative culture development of the future manager of general secondary educational institution are the following:

- gnosticism, which helps to streamline the research position on the possibility of the correct and adequate development to modern reality model of the innovative culture development of the individual, promotes conscious and scientific knowledge, as well as recognition of the results of such scientific analysis of innovative culture [1, p. 25];

- scientific;

- objectivity;

- historicism;

- unity of historical and logical;

- object-specificity, provides

accurate

and clear definition of the object, subject and research methods, which are aimed at developing theoretical and methodological foundations for the new image formation of the modern leader with a high innovative culture level and a significant share of intellectual component in human capital; this principle of the dialectical approach to scientific research provides structuring of research according to such components as target, theoretical-methodological, contextual, organizational-methodical, professionalpedagogical and effective-prognostic [4, p. 16], which allows to specify subject-subject area of research and determine its main tasks, among which the priority belongs to the definition of current trends in the innovative culture development of the future manager of general secondary educational institution in the system of continuing education; model substantiation of the innovative culture development of the future manager of general secondary educational institution; valid methods and techniques development for diagnosing the level of the innovative culture development of the future managers of the educational institution, etc.;

- systematic;

- multifactorial;

- empirical analysis;

- comprehensiveness;

- specificity;

- interdisciplinarity;

- unity of theory and practice;

- polyconceptuality.

Within the philosophical level of the theoretical and methodological principles, great importance belongs to the system and synergetic methodological approaches, which in many respects complement each other.

The systems approach methodology, first of all, allows to analyze the subject of research from the point of view of such characteristics as integrity, stability, openness, structure, interconnectedness of elements, hierarchy, etc. The point is that the problem of the innovative culture development of the future manager of general secondary educational institution in the masters' training process should be considered holistically and systematically, studying both its ideological-theoretical and value, and institutional, practice-oriented dimensions. E. Yudin, analyzing the content of the systems approach, drew attention to a number of priorities for the study of certain reality objects, in particular: when studying the object as a system, the elements description is not special, because each element is described not as such, but places in general; each system has an internal hierarchy that requires system management; the study of the system is inseparable from the study of the conditions of its functioning; an important aspect is the generation analysis of the properties of the whole from its elements properties and vice versa, etc. [9, p. 103]. Thus, it is a systematic approach that allows to identify and justify the structure of individual' innovative culture to trace the interdependence and hierarchy of its specific components, to conclude about the integrity and complexity of innovative culture as a sociocultural phenomenon [2; 3, p. 38]. 
Essential for understanding the innovative culture is a synergetic approach, the key idea of which is systems self-development idea. Synergetic methodology involves consideration of the innovative culture development of the individual as selforganization process, testifies to the research position that any system condition is the constant change and self-renewal while maintaining the integrity of their structure; moreover, the synergetic approach allows to consider the innovative culture development as a social, educational and cultural phenomenon, the improvement of which meets such criteria as versatility, nonlinearity, dynamism, interconnectedness of all elements, their selforganization and self-development; synergetic methodology corresponds to the world modern dynamics development, the necessary basis of which is an innovative culture [7, p. 10].

The specifically scientific level of theoretical and methodological principles is represented by a number of methodological approaches, the theoretical tools of which are the basis for research structuring, setting out its main theoretical provisions and scientific conclusions. These are such methodological approaches as the actual professional-pedagogical, anthropological, sociocultural, culturological, paradigmatic, civilizational, formational, axiological, problem, thesaurus, phenomenological, acmeological, praxeological, hermeneutic, between which there is a need for methodological integration.

The conceptual-theoretical level of theoreticalmethodological bases is represented by the leading positions of the modern theory of pedagogical cognition; state and international documents governing the innovations and innovative activities development; conceptual provisions of the research source base (monographs, dissertations, abstracts of dissertations, scientific articles, etc.), which gave grounds for reasonable and objective conclusions on the innovative culture development of the individual; theoretical and conceptual provisions for understanding the pedagogical essence of innovation and the innovative culture development of the future manager of general secondary educational institution.

The theoretical research basis are:

- modern fundamental provisions for the innovative development of educational space (V. Andrushchenko, I. Bekh, G. Vasyanovich, L. Vakhovsky, B. God, I. Zyazyun, V. Kremen and others);

- the latest scientific and theoretical approaches to the formation of pedagogical knowledge (O. Adamenko, S. Goncharenko, O. Dzhurinsky, G. Kornetov, V. Kremen, N. Nichkalo, A. Sbrueva, S. Sysoeva, O. Sukhomlinska and others);

- historical and pedagogical provisions on the patterns of education development (L. Berezivska,
V. Bugriy, L. Vakhovsky, N. Gupan, M. Yevtukh, O. Lavrinenko, O. Mykhailychenko and others);

- conceptual provisions on the innovative culture essence of modern personality (V. Andrushchenko, L. Gubersky, T. Gavlitina, L. Danylenko, L. Dychkivska, O. Ilkiv, K. Kyrylenko, L. Kravchenko, V. Kremen, O. Starovoit, L. Stefan and others);

- scientific-theoretical generalizations on the content and methods of masters' training (V. Berek, V. Kurok, O. Mikheenko, O. Semenog, L. Sushchenko and others);

- theoretical and conceptual provisions on the management of educational activities (M. Grynyova, L. Danylenko, G. Yelnikova, Y. Ryabova and other).

Methodological and technological level of theoretical and methodological principles is represented by research methods system, as well as the stages of its implementation. To develop the theoretical and methodological foundations for the innovative culture development of the future manager of general secondary educational institution, we used a set of general theoretical, empirical and special research methods.

The first methods group is represented by general theoretical ones, to which we include analysis, synthesis, induction, deduction, generalization, comparison, systematization, generalization, interpretation, classification, etc. Relevant research tools are designed to ensure the scientific research procedure, theoretical analysis and generalization, to create the necessary opportunities for systematic analysis of domestic and foreign research, which deals with theoretical and methodological principles of the individual's innovative culture.

The second methods group is empirical. These include interviews, questionnaires, testing, surveys, pedagogical observation, expert evaluation, etc. Appropriate methodology allows to collect and accumulate the necessary material, which creates opportunities for theoretical generalizations. Implementation of the principles and tools of empirical methods creates opportunities for diagnosing the innovative culture level of the future manager of general secondary educational institution, focuses on meticulous collection and analysis of empirical material, which is the basis for developing appropriate pedagogical methods.

The third methods group includes special, among which we use the following:

1) the method of actualization of professional and pedagogical problems, which helps to identify and study important contexts of the research topic, allows its consideration in accordance with modern social and pedagogical contradictions;

2) method of comparative pedagogical analysis - in order to determine the scientists' common and different approaches to the theoretical 
and methodological research principles development, determining the specific characteristics of personality's innovative culture, comparing levels, stages, criteria and indicators of its development;

3) historical-genetic (chronological) method - to determine the conditions, stages, patterns, features, contradictions of the innovative culture development of the future manager of the educational sphere;

4) structural-logical and structural-functional methods that focus research on a systematic analysis of the innovative culture essence, its methods development in the process of masters' training;

5) method of terminological selection - for selection and substantiation of conceptual and categorical apparatus, research, disclosure of content and clarification of the key terms essence, concepts and categories;

6) method of pedagogical experiment - to confirm the effectiveness of the prepared and substantiated methods of the innovative culture development of the future manager;

7) statistical methods (mathematical processing of quantitative results of the conducted ascertaining and forming experiments), which allowed to confirm the objectivity and reliability of the developed method.

Conclusions and prospects of further research. So, in the model of the research methodology of theoretical and methodical bases of the innovative culture development of the future manager of general secondary educational institution in the masters' training process, where philosophical, concretescientific, conceptual-theoretical and methodicaltechnological levels are structurally offered. The methodological potential provides the necessary theoretical opportunities for a holistic, scientific and relevant solution of the tasks set in the article. At the philosophical and methodological level, the heuristic possibilities of dialectical theory, systemic and synergetic methodological approaches are outlined, and a number of scientific principles and pedagogical research are traced. At the level of concrete-scientific methodology the methodological potential of professionalpedagogical, anthropological, sociocultural, culturological, paradigmatic, civilizational, formational, axiological, problem, thesaurus, phenomenological, acmeological, praxeological and hermeneutic approaches and hermeneutics are integrated. At the third conceptual-theoretical level the leading provisions of modern theory of pedagogical cognition, professional pedagogy is systematized, scientific generalizations on methods of the innovative culture development of the future manager are studied, the provisions of leading state and international documents regulating innovations and innovative activity development are taken into account. Instead, at the fourth methodological and technological level, a set of general theoretical, empirical and special methods is presented, which allowed to carry out the necessary operations for empirical collection, theoretical analysis and generalization of research materials. The corresponding methodological model corresponds to the tasks set in the article, and also takes into account the interdisciplinary specifics of the subject of research.

The prospects for the further research contain the development of the methodical tools of the innovative culture development of the future manager of the secondary educational institution in the magister training process.

\section{References:}

1. Бобрышов С.В. Методология историко-педагогического исследования развития педагогического знания : автореф. дисс. ... докт. пед. наук : 13.00.01 ; Негосударственное образовательное учреждение «Северо-Кавказский социальный институт». Ставрополь, 2006. $40 \mathrm{c}$.

2. Богуславский М.В., Милованов К.Ю. Перспективы развития историко-педагогического знания. Отечественная и зарубежная педагогика. 2016. № 3(30). С. 25-32.

3. Богуславський М.В. Структура сучасного історико-педагогічного знання. Шлях освіти. 1999. № 1. С. $37-40$.

4. Бойченко М.А. Теоретичні та методичні засади освіти обдарованих школярів у США, Канаді та Великій Британії : автореф. дисс. ... докт. пед. наук. Суми, 2019. 44 с.

5. Босенко В.А. Всеобщая теория развития. Киев, 2001. $468 \mathrm{C}$.

6. Дубасенюк О.А. Формування методологічної культури молодого дослідника у процесі його наукового становлення у сфері педагогіки. Профресійна освіта: педагогіка і психологія / за ред. Т. Левовицького, І. Вільш, І.А. Зязюна, Н.Г. Ничкало. Ченстохова ; Київ, 2009. Вип. ХІ. С. 67-74.

7. Кремень В.Г. Педагогічна наука: час методологічної рефрлексії. Педагогіка і психологія. 1998. № 2. C. 9-15.

8. Ничкало Н.Г. Профресійна педагогіка і психопедагогіка праці у діалектичному взаємозв'язку. Теорія і практика управління соціальними системами. 2013. № 2. С. 42-53.

9. Юдин Э.Г. Системный подход и принцип деятельности. Методологические проблемы современной науки. Москва : Наука, 1978. $391 \mathrm{c}$. 
Козлов Д. О. Методологічні засади дослідження проблеми розвитку інноваційної культури майбутнього керівника закладу загальної середньої освіти у процесі магістерської підготовки

Методологія дослідження проблеми розвитку інноваційної культури майбутнього керівника закладу загальної середньої освіти у процесі магістерської підготовки відповідає специфіці теми та враховує їі системність і міждисциплінарність. 3 огляду на це теоретико-методологічні засади розглянуто на чотирьох наукових рівнях: фрілософьському, конкретно-науковому, концептуально-теоретичному, методико-технологічному. Такий підхід дав змогу побудувати дослідження з урахуванням необхідних фрілософрських і науково-теоретичних положень, дотримуватися тих методологічних орієнтирів, які забезпечили науковість аналізу, посилили логіку викладу, зорієнтували на цілісність і всебічність дослідження.

У статті запропоновано модель методології дослідження теоретичних і методичних засад розвитку інноваційної культури майбутнього керівника закладу загальної середньої освіти у процесі магістерської підготовки, у якій структурно впорядковано фрілософрський, конкретно-науковий, концептуально-теоретичний та методико-технологічний рівні. Зазначено, що на фрілософському методологічному рівні окреслено евристичні можливості діалектичної теорії, системного та синергетичного методологічних підходів, а також простежено низку принципів проведення науково-педагогічного пошуку. Встановлено, що на рівні конкретно-наукової методології інтегровано методологічний потенціал професійно-педагогічного, антропологічного, соціокультурного, культурологічного, парадигмального, цивілізаційного, фрормаційного, аксіологічного, проблемного, тезаурусного, фееноменологічного, акмеологічного, праксеологічного та герменевтичного підходів, підкреслено важливість їх інтеграції й диверсифрікації. Презентовано, що на третьому концептуально-теоретичному рівні систематизовано провідні положення сучасної теорії педагогічного пізнання, профресійної педагогіки; вивчено наукові узагальнення щодо методики розвитку інноваційної культури особистості; враховано положення провідних державних і міжнародних документів, що регулюють розвиток інновацій та інноваційної діяльності. Визначено, що на четвертому методико-технологічному рівні представлено сукупність загальнотеоретичних, емпіричних і спеціальних методів, які дали змогу провести необхідні операції щодо емпіричного збору, теоретичного аналізу та узагальнення матеріалів дослідження. Відповідна методологічна модель відповідає поставленим у статті завданням, а також враховує міждисциплінарну специфріку предмета дослідження.

Ключові слова: інновації, інноваційна культура, майбутній керівник, заклад загальної середньої освіти, процес магістерської підготовки, методологічні засади, методичні підходи. 